\title{
Nt-proBNP DISCRIMINATORY ROLE BETWEEN SYMPTOMATIC AND ASYMPTOMATIC PATIENTS WITH SEVERE VALVULAR AORTIC STENOSIS
}

\author{
Emilija Antova $^{1}$, Lidija Petkovska ${ }^{2}$, Marijan Bosevski ${ }^{1}$, Jagoda Stojkovik ${ }^{3}$, \\ Nikola Hadzy-Petrushev ${ }^{4}$, Andre Kamkin ${ }^{5}$, Mitko Mladenov ${ }^{4,5}$ \\ ${ }^{1}$ Medical Faculty, University Clinic of Cardiology, "Ss. Cyril and Methodius" University, 1000 Skopje, Repubic of Macedonia \\ ${ }^{2}$ Medical Faculty, University Clinic of Toxicology, "Ss. Cyril and Methodius" University, 1000 Skopje, Repubic of Macedonia \\ ${ }^{3}$ Medical Faculty, University Clinic of Pulmology, "Ss. Cyril and Methodius" University, 1000 Skopje, Repubic of Macedonia \\ ${ }^{4}$ Faculty of Natural Sciences and Mathematics, Institute of Biology, "Ss. Cyril and Methodius" University, Skopje, Repubic of Macedonia \\ ${ }^{5}$ Department of Fundamental and Applied Physiology, Russian National Research Medical University, Russia
}

Corresponding author: Assoc. prof. Mitko I. Mladenov, PhD, Faculty of Natural Sciences and Mathematics, Institute of Biology, "Ss. Cyril and Methodius" University, P.O. Box 162, 1000 Skopje, Macedonia, Phone: ++38923249605, Fax: ++38923228141, Email: m.mitko@gmail.com

\section{ABSTRACT}

Background: The aim was to evaluate the Nt-proBNP discriminatory role between symptomatic and asymptomatic patients with severe aortic stenosis.

Methods: 187 patients with severe valvular aortic stenosis, with normal $\mathrm{EF}>50 \%$, were included, 61 asymptomatic and 126 symptomatic. We used clinical, laboratory (Nt-proBNP) and echocardiographic parameters. Endpoints of monitoring (occurrence of event) were: the onset of symptoms in asymptomatic patients and death in both groups.

Results: The symptomatic group with severe AS had a significantly higher means of Nt-proBNP, in comparison with the asymptomatic group. Nt-proBNP was a significant predictor for the risk of event occurrence (HR 1.4). In the group of severe AS without CAD $(n=101)$, the subgroup with Nt-proBNP above the cut-off value, took significantly higher percentage of patients with chest pain, fatigue and syncope. In the group with Nt-proBNP above the cut-off value, we had a significantly higher percentage of patients with severe AS without CAD, compared to those with CAD $(\mathrm{n}=142)$. Nt-proBNP was negatively correlated with AVA and LVEF, whether the positive correlation was expressed for: LVEDd, LVEDs, IVSd, AV_Vmax, AV_MaxGrad, LVM and LA. Patients with Nt-proBNP above the cut-off, had a significantly lower event free survival, compared to patients with Nt-proBNP below the cut-off $(n=187 ; n=101)$.

Conclusion: The Nt-proBNP cut-off $>460 \mathrm{pg} / \mathrm{ml}$ was confirmed as a useful tool in the determination of event free survival in patients with severe AS. Nt-proBNP not only had relevance in the assessment of the severity of the disease, but also was a significant predictor for the risk of event occurrence.

Keywords: Aortic stenosis; N-terminal pro-B-type natriuretic peptide; Echocardiography; Aortic valve replacement

\section{INTRODUCTION}

Aortic stenosis (AS), is one of the most common valvular diseases, with increased incidence in conjunction with increased life expectancy, i.e., in the larger percentage, it is an elderly disease. $[1,2,3]$
Aortic valvular stenosis is a chronic progressive disease. In it evolutionary course, two periods are changed: an asymptomatic and a symptomatic period, based on which the patients are divided into two groups: asymptomatic and 
symptomatic. The duration of the asymptomatic phase, which may last for decades, varies widely among patients. Also, there is a great individual variability, and some have a quick, and some have a slow evolutionary course, some of them will be symptomatic and some not, despite the existence of a severe aortic valvular stenosis. This depends on the existence and duration of coronary artery disease (CAD), hypertension, renal disease, pulmonary disease and other adjunct conditions, or comorbidities. On the other hand, light symptoms such as a slight decrease in effort tolerance, lack of air during exposure to effort, easy fatigue, occasional darkness in the eyes, often remain masked with old age and usually remain undeclared during the examination. It is difficult to answer whether the symptoms mentioned by the patient are precisely due to aortic valvular stenosis or some other comorbidities. But their clinical demarcation is of utmost importance for further management.

The progression of the disease from mild, through moderate to severe can be followed by regular cardiologic and echocardiographic examinations. Echocardiography has the most important place in the detection of the disease, the monitoring of patients and making the decision whether and when is the best optimal time for the patient to refer to a surgical treatment (aortic valve replacement - AVR) or to an interventional treatment (transcateter aortic valvular implantation-TAVI) to the valvular aortic stenosis. [1, 2, 3] Postponement of it, due to unrecognized symptoms and echocardiographic parameters, will lead to significant deterioration, with development of heart failure, death or increased operative risk.

In recent years there was a tendency to find other predictive factors that would contribute to the risk of stratification and management of asymptomatic and symptomatic patients with severe valvular aortic stenosis, with particular reference to the significance of the laboratory parameter Nt-proBNP.

The aim of the study was to evaluate the Nt-proBNP discriminatory role between asymptomatic and symptomatic patients with severe valvular aortic stenosis.

\section{MATERIALS AND METHODS}

\section{Patients' characteristics}

This was a single-center prospective study in 187 consecutive patients with symptomatic and asymptomatic severe valvular AS (with rheumatic and degenerative etiology). Severe AS was defined according to echocardiographic criteria (AV_max $>4 \mathrm{~m} / \mathrm{s}$, maximum transvalvular gradient $\mathrm{LV} / \mathrm{Ao}$ of $>64 \mathrm{mmHg}$, an aortic valve area (AVA) $<1 \mathrm{~cm}^{2}$ and moderate or severe aortic valvular calcification. Only patients with normal systolic ventricular function (left ventricular ejection fraction (LVEF) $>50 \%$ ) were included in the study. The patients with mild and moderate AS, patients with severe AS with low gradient and reduced LV function, patients with acute myocardial infarction, renal disease, severe lung disease, anaemia and those with other significant valve diseases were excluded from the study. Patient monitoring: Asymptomatic patients with severe AS were monitored clinically, echocardiography, and Nt-proBNP were determined every 6 months after the first review. All three trials were repeated even earlier, immediately after the onset of any symptom.

All symptomatic patients with severe AS were offered AVR. The symptomatic patients who rejected the proposed AVR, were subjected to further monitoring, with repeated echocardiography and Nt-proBNP determination every 6 months after the first review if no death occurred in the meantime. Endpoints of monitoring (occurrence of event) were: the onset of symptoms in asymptomatic patients (which meant referral to aortic valvular replacement) and death in both groups.

Patients were treated according to the ESC/EACTS and AHA/ACC Guidelines for the management of valvular heart disease. $[1,3]$ The study conformed to the principles outlined in the Helsinki Declaration and was approved by the Institutional Review Board (Ethics Committee of the Medical Faculty at the University "Ss. Cyril and Methodius" in Skopje).

\section{NYHA Functional Classification}

All examined patients with severe AS were divided into three New York Heart Association (NYHA) functional classes. There were no patients in the fourth class according to the criteria of LVEF $>50 \%$. Respectively, in the first NYHA class of this study there were $91(49 \%)$ patients, $54(29 \%)$ in the second, and $42(22 \%)$ in the third class (Table 2).

\section{Transthoracic Echocardiography}

All studies were performed using Agilent Image Point $\mathrm{Hx}$ with $3.5 \mathrm{~Hz}$ Probe. We used M-mode, pulsed, and continuous-wave Dop- 
pler measurements to obtain the most important parameters for assessing the severity of AS. Parameters: Left ventricular: end-diastolic (LVEDd) and end-systolic inner diameter (LVEDs), Maximal aortic transvalvular velocity ( $\left.\mathrm{AV} \_\mathrm{Vmax}\right)$, Maximal aortic transvalvular gradient ( $\overline{\mathrm{A}} \mathrm{V} \_\mathrm{Max}$ Grad.), Aortic valve area (AVA), Thickening of the interventricular septum in diastole (IVSd) and left ventricular posterior wall (LVPWd) in the diastole, left ventricular mass (LVM) and left atrium (LA) were measured according to the criteria given in the European and American recommendations for the quantification and evaluation of valvular stenosis. [4, 5, 6] Echocardiographic measurements were performed on sinus beats, avoiding the first post-extrasystolic beat if feasible. The LV ejection fraction was calculated using the M-mode and Teicholtz formula. Maximal aortic transvalvular velocity (AV_Vmax) was recorded with continuous-wave Doppler utilizing a multi window approach. Maximal transvalvular gradient was calculated with the Bernoulli equation (AV_Max.Grad $=4 \times$ AV_Vmax ${ }^{2}$ ). The Aortic tive statistics: (mean value and standard deviation). In the segment of the inferential statistics, for comparison of the continuous variables, we applied: student t-test, nonparametric tests and/ or analysis of variance (ANOVA), i.e. to compare the categorical variables we employed $\chi 2$ test. The coefficient of correlation between certain variables was determined by the Pearson coefficient of linear correlation. The ROC (receiver operating curve) analysis was used to determine the sensitivity/specificity of certain determined parameters. Based on the previously determined linear association between the tested parameters, a model with prognostic variables was constructed. The model was evaluated using the multivariate logistic regression analysis in order to determine statistically significant independent predictors of the disease progression.

To determine the time free from the occurrence of unwanted events-event free survival, we employed the Cox regression model by constructing Kaplan-Mayer curves and we evaluated their difference by using a log-runk test.

Table 1. Clinical parameters (age/gender) and Nt-proBNP values in total group,

\begin{tabular}{|c|c|c|c|c|}
\hline & All patients & $\begin{array}{l}\text { Asymptomatic } \\
\text { patients }\end{array}$ & $\begin{array}{l}\text { Symptomatic } \\
\text { patients }\end{array}$ & $\mathrm{p}$ \\
\hline Age (yrs. mean \pm SD) & $61.6 \pm 11.8$ & $59 \pm 13$ & $63 \pm 11$ & 0.035 \\
\hline Age (>50 yrs. \%) & 85 & 80 & 87 & \\
\hline $\operatorname{Man}($ n. \%) & $97(52 \%)$ & $36(59 \%)$ & $61(48 \%)$ & I \\
\hline Nt-proBNP (pg/ml) & $739 \pm 671$ & $404 \pm 425$ & $901 \pm 709$ & 0.0001 \\
\hline
\end{tabular}

Aortic stenosis (AS), N-terminal pro-brain natriuretic peptide (Nt-proBNP).

Valve area (AVA) was calculated by the continuity equation $[4,5,6]$. The degree of aortic valve calcification was assessed from echocardiographic zoomed short-axis views and scored on a 4-grade scale according to Rosenhek et al. (2002). [7]

\section{Blood}

Venous blood was taken for the analysis of the laboratory parameter Nt-proBNP. A chemiluminescent in vitro immunoassay was used, for the quantitative determination of Nt-proBNP in human serum (ProBNP Elecsys, Roche Diagnostics $\mathrm{GmbH}$ ).

Coronary angiography was conducted in cases when decision was made to refer patients to aortic valve replacement (AVR).

\section{Statistical Analysis}

For the description of the variables from the patients database we used standard descrip-

\section{RESULTS}

In our prospective study we analyzed 187 patients with severe valvular AS. Asymptomatic patients were monitored for 2-36 months, with a mean follow-up period of $19.5 \pm 10$ months, while symptomatic patients were monitored for 3-8 months with a mean follow-up period of $25.4 \pm 16.4$ months.

Association between Nt-proBNP and Clinical Expression of Severe AS

One of the basic aims of the study was to examine whether there was any association between Nt-proBNP and clinical expression of AS. Our data showed that the symptomatic group has a significantly higher means for age and Nt-proBNP in comparison with the asymptomatic group with severe AS $(t=2.1, d f=183, p<0.03 ; t=5.95, d f=177$, 
$\mathrm{p}<0.0001$, respectively) (Table 1 ). At the same time, there was a significant positive correlation $(\mathrm{r}=0.21$, $p<0.003)$, between age and Nt-proBNP $(n=187)$.
Multivariate Cox regression analysis of event occurrence $(n=187)$, based on Nt-proBNP, AV_Vmax and NYHA III, showed that only

Table 2. Patients distribution according New York Heart Association (NYHA)

functional classes and their Nt-proBNP means $\pm S D$.

\begin{tabular}{lcl} 
& $\begin{array}{c}\text { NYHA functional } \\
\text { classes from total }\end{array}$ & $\begin{array}{l}\text { Nt-proBNP } \\
\text { means } \pm \text { SD }(\mathrm{pg} / \mathrm{ml})\end{array}$ \\
\hline NYHA I & $49 \%$ & $565 \pm 593$ \\
NYHA II & $29 \%$ & $757 \pm 423$ \\
NYHA III & $22 \%$ & $1093 \pm 918$
\end{tabular}

New York Heart Association(NYHA)

Table 3. Association between Nt-proBNP and chest pain in patients without CAD.

\begin{tabular}{llll}
\hline & Without chest pain & With chest pain & Total \\
\hline Nt-proBNP $(\leq 460 \mathrm{pg} / \mathrm{ml} ;$ n. \%) & $19(52.8)$ & $12(18.5)$ & $31(30.7)$ \\
Nt-proBNP $(>460 \mathrm{pg} / \mathrm{ml} ;$ n. \%) & $17(47.2)$ & $53(81.5)$ & $70(69.3)$ \\
Total (n. \%) & $36(100)$ & $65(100)$ & $101(100)$
\end{tabular}

Coronary artery disease (CAD). N-terminal pro-brain natriuretic peptide (Nt-proBNP)

Table 4. Association between Nt-proBNP and fatigue in patients without CAD.

\begin{tabular}{lcll}
\hline & $\begin{array}{l}\text { Without } \\
\text { fatigue }\end{array}$ & $\begin{array}{l}\text { With } \\
\text { fatigue }\end{array}$ & Total \\
\hline Nt-proBNP $(\leq 460 \mathrm{pg} / \mathrm{ml} ; \mathrm{n} . \%)$ & $12(66.7)$ & $19(22.9)$ & $31(30.7)$ \\
Nt-proBNP $(>460 \mathrm{pg} / \mathrm{ml} ;$ n. \%) & $6(33.3)$ & $64(77.1)$ & $70(69.3)$ \\
Total $(\mathrm{n} . \%)$ & $18(100)$ & $83(100)$ & $101(100)$
\end{tabular}

Abbreviations for CAD and Nt-proBNP are the same as in Table 3.

Table 5. Association between Nt-proBNP and syncope in patients without CAD.

\begin{tabular}{|c|c|c|c|}
\hline \multicolumn{4}{|c|}{$\begin{array}{ll} & \text { Syncope }\end{array}$} \\
\hline & without syncope & only one time-syncope & many times-syncope \\
\hline Nt-proBNP $(\leq 460$ pg/ml; n. \%) & $28(39.4)$ & $1(8.3)$ & $2(11.1)$ \\
\hline Nt-proBNP (> 460 pg/ml; n. \%) & $43(60.6)$ & $11(91.7)$ & $16(88.9)$ \\
\hline Total (n. \%) & $71(100)$ & $12(100)$ & $18(100)$ \\
\hline
\end{tabular}

Abbreviations for CAD and Nt-proBNP are the same as in Table3.

Table 6. Frequency of patients with severe AS, with and without CAD, underwent coronary angiography.

\begin{tabular}{lll}
\hline & Number & $\%$ \\
\hline Severe AS, without CAD (n. \%) & 101 & $71 \%$ \\
Severe AS, with CAD (n. \%) & 41 & $29 \%$ \\
Total (n. \%) & 142 & $100 \%$
\end{tabular}

Abbreviations for AS and CAD are the same as in Table 1 and Table 3.

\section{Association between Nt-proBNP and}

\section{NYHA Functional Classification}

Our data showed that Nt-proBNP values increased with the worsening of NYHA functional classes (Table 2). Actually, Nt-proBNP was significantly different between all three NYHA functional classes $(\mathrm{df} 1=2, \mathrm{df} 2=184, \mathrm{p}<0.0001)$.

The Univariate Cox-regression analysis outlined Nt-proBNP as a predictor with significant influence on the risk of event occurrence (occurrence of symptoms and/or death) with a hazard ratio (HR) of 1.4 (95\% confidence interval $(\mathrm{CI}) 1.5$ to $1.69, \mathrm{p}<0.001)(\mathrm{n}=187)$.
Nt-proBNP could be taken as a predictor of event occurrence. Precisely, Nt-proBNP increased the risk of event occurrence to 1.39 (95\% CI 1.13 to 1.70). Conversely, AV_Vmax and NYHA III cannot be taken as significant predictors of events. Applying the same analytical subset on Nt-proBNP and NYHA II, indicated that both parameters have noteworthy impact on the event occurrence. In actuality, Nt-proBNP increased the risk of event occurrence to 1.47 times (95\% CI 1.13 to 1.90 , $\mathrm{p}<0.004)$; while for NYHA II it was 1.56 times (95\% CI 1.03 to $2.36, \mathrm{p}<0.033$, respectively). 


\section{Association between Nt-proBNP and Clinical Symptoms}

In the following part, the association between Nt-proBNP and symptoms: chest pain, fatigue and syncope in the 101 patients without CAD (existence of CAD was excluded with coronarography) were analyzed ( $\mathrm{n}=101)$.

In the group without $\mathrm{CAD}$, of all patients with chest pain (65 patients) $82 \%$ had Nt-proBNP values above the cut-off, compared to $47 \%$ without chest pain who had Nt-proBNP above the cutoff, $(\chi 2=2.8, \mathrm{df}=1, \mathrm{p}<0.0001)$ (Table 3).

In the group without $\mathrm{CAD}$, of all patients with fatigue $77 \%$ had Nt-proBNP values above the cut-off, compared to $33 \%$ in the group without fatigue having Nt-proBNP above the cut-off value. The association is statistically significant $(\chi 2=13.3, \mathrm{df}=1, \mathrm{p}<0.001)$ (Table 4).

Furthermore, from Table 5, it is evident that in the group without CAD from all those who have lost consciousness, 90\% have Nt-proBNP values above the cut-off value, compared with $60.6 \%$ of all patients who have not lost consciousness, and have Nt-proBNP above the cut-off value. The association is statistically significant $(\chi 2=8.6, \mathrm{df}=2, \mathrm{p}<0.013)$.

\section{Association between Nt-proBNP and Cor- onary Angiography}

In 142 patients who underwent coronary angiography, the findings were as follows: severe AS without CAD were 101 patients (71\%), and severe AS with CAD were 41 patients (29\%) (Table 6).

The frequency distribution from the obtained Nt-proBNP values in all 187 patients is shown in (Figure 1).



Figure 1. Frequency distributions from obtained NtproBNP values in all 187 patients.
Patients with Severe AS with Normal Coronary Angiography Findings

In the group with regular coronary angiography $(n=101), 70(69.3 \%)$ patients had an average value of Nt-proBNP above the cut-off of $460 \mathrm{pg} / \mathrm{ml}$, and $31(30.7 \%)$ had values below the cut-off value. This difference is statistically significant $(\mathrm{t}=4.2, \mathrm{df}=100 \mathrm{p}<0.05)$, (Table 7).

From all symptomatic patients, $85.3 \%$ had Nt-proBNP values above the cut-off, compared to $23.1 \%$ of all asymptomatic patients who had Nt-proBNP values above the cut-off. Frequency distribution analysis between these two groups in relation to the Nt-proBNP threshold value showed a significant difference $(\chi 2=35.2, \mathrm{df}=1$, $\mathrm{p}<0.0001)(\mathrm{n}=101)($ Table 7).

In the group with Nt-proBNP above the cut point, $32.7 \%$ were patients with severe AS with CAD compared to $67.3 \%$ patients with severe AS without CAD. Statistical analysis showed a statistically significant difference $(\mathrm{t}=3.7$, df $=$ $103, p<0.05)$ in benefit of greater prevalence of patients with AS who do not have CAD, and have Nt-proBNP above the cut-off value $(\mathrm{n}=$ 142) (Table 8).

Figure 2. A: Survival curves in patients with severe aortic stenosis with and without $C A D$.
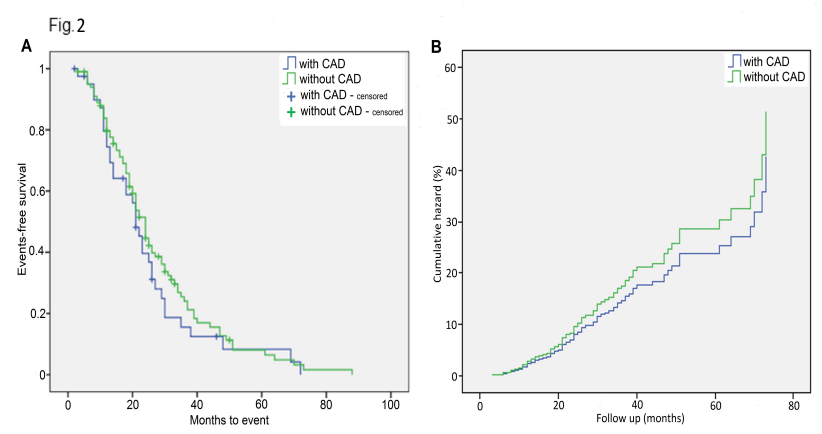

$B$ : Cumulative hazard of event occurrence, in dependence of CAD in patients with severe aortic stenosis.

The frequency distribution analysis of the patients with Nt-proBNP above and below the cut point, in relation to the patients with severe $\mathrm{AS}$, with and without CAD, was insignificant $(\mathrm{p}=0.09),(\mathrm{n}=142)$ (Table 8).

At the same time, the t-test showed insignificant differences $(t=-1.13, d f=140, p=0.25)$ for Nt-proBNP average values, between the two group patients with severe AS with and without CAD (n=142).

Applying the Kaplan-Meier survival model to the same onset, showed that the aver- 
Table 7. Distribution of asymptomatic/symptomatic patients in the group with normal coronary angiography findings in dependence of Nt-proBNP cut-off values.

\begin{tabular}{lccc}
\hline & \multicolumn{2}{c}{ Asymptomatic-Symptomatic } \\
& Asymptomatic & Symptomatic & Total(n. \%) \\
\hline Nt-proBNP $(\leq 460 \mathrm{pg} / \mathrm{ml} ;$ n. \%) & $20(76.9)$ & $11(14.7)$ & $31(30.7)$ \\
Nt-proBNP $(>460 \mathrm{pg} / \mathrm{ml} ;$ n. \%) & $6(23.1)$ & $64(85.3)$ & $70(69.3)$ \\
Total (n. \%) & $26(100)$ & $75(100)$ & $101(100)$
\end{tabular}

Abbreviation for Nt-proBNP is the same as in Table 3.

Table 8. Distribution of CAD among 142 patients with coronary angiography, in dependence of cut-off Nt-proBNP values.

\begin{tabular}{lcccc}
\hline \multicolumn{5}{c}{ Nt-proBNP } \\
\multicolumn{1}{c}{$\begin{array}{c}\text { Nt-proBNP } \\
(\leq 460 \mathrm{pg} / \mathrm{ml})\end{array}$} & $\begin{array}{c}\text { Nt-proBNP } \\
(>460 \mathrm{pg} / \mathrm{ml})\end{array}$ & Total \\
\hline \multicolumn{2}{l}{ Severe AS Without CAD (n. \%) } & $31(81.6)$ & $70(67.3)$ & $101(71.1)$ \\
Severe AS With CAD & (n. \%) & $7(18.4)$ & $34(32.7)$ & $41(28.9)$ \\
Total (n. \%) & & $38(100)$ & $104(100)$ & $142(100)$ \\
\hline
\end{tabular}

Aortic stenosis (AS), Abbreviations for CAD and Nt-proBNP are the same as in Table 3.

Table 9. Distribution of asymptomatic/symptomatic patients in dependence of CAD among 142 patients with severe AS.

\begin{tabular}{lccc}
\hline & \multicolumn{3}{c}{ CAD } \\
& without CAD & with CAD & \multicolumn{1}{c}{ Total } \\
\hline Asymptomatic (n. \%) & $26(25.7)$ & $5(12.2)$ & $31(21.8)$ \\
Symptomatic (n. \%) & $75(74.3)$ & $36(87.8)$ & $111(78.2)$ \\
Total (n. \%) & $101(100)$ & $41(100)$ & $142(100)$ \\
\hline
\end{tabular}

Abbreviations for AS and CAD are the same as in Table 1 and Table 3 respectively.

Table 10.a. Echocardiographic parameters in total 187 patients, (asymptomatic and symptomatic patients with severe AS.)

\begin{tabular}{lccll}
\hline $\begin{array}{l}\text { Echocardiographic } \\
\text { parameters }\end{array}$ & All patients & $\begin{array}{c}\text { Asymptomatic } \\
\text { patients }\end{array}$ & $\begin{array}{l}\text { Symptomatic } \\
\text { patients }\end{array}$ & $\mathrm{p}$ \\
\hline EF $(\%)$ & 66 & 69 & 65 & 0.0001 \\
IVSd $(\mathrm{mm})$ & 15 & 14 & 15 & 0.12 \\
AV_Vmax $(\mathrm{m} / \mathrm{s})$ & 4.6 & 4.3 & 4.7 & 0.0001 \\
AV_Vmax.Grad $(\mathrm{mmHg})$ & 85 & 75 & 90 & 0.0001 \\
AVA $\left(\mathrm{cm}^{2}\right)$ & 0.75 & 0.81 & 0.69 & 0.0001 \\
Nt pro-BNP $(\mathrm{pg} / \mathrm{ml})$ & 739 & 404 & 901 & 0.0001
\end{tabular}

Table 10.b. Correlation between Nt-proBNP and Echocardiographic parameters.

\begin{tabular}{lcl}
\hline $\begin{array}{l}\text { Echocardiographic } \\
\text { parameters }\end{array}$ & $\mathrm{r}$ & $\mathrm{p}$ \\
\hline EF $(\%)$ & -0.28 & 0.0001 \\
IVSd $(\mathrm{mm})$ & 0.17 & 0.015 \\
AV_Vmax $(\mathrm{m} / \mathrm{s})$ & 0.19 & 0.008 \\
AV_Vmax.Grad $(\mathrm{mmHg})$ & 0.19 & 0.008 \\
AVA $\left(\mathrm{cm}^{2}\right)$ & -0.19 & 0.009 \\
LVEDd $(\mathrm{mm})$ & 0.23 & 0.001 \\
LVEDs $(\mathrm{mm})$ & 0.28 & 0.0001 \\
LA $(\mathrm{mm})$ & 0.23 & 0.001 \\
LVM $(\mathrm{g})$ & 0.32 & 0.0001
\end{tabular}

Abbreviations for Table 10a and 10b: Ejection fraction (EF), Interventricular septum in diastole (IVSd), Maximal aortic transvalvular velocity (AV $\mathrm{V}_{\max }$ ), Maximal aortic transvalvular gradient (AV_Max.Grad), Aortic valve area (AVA), Left ventricul end-systolic diameter (LVEDs), Left ventricul end-diastolic diameter (LVEDd), Left atrium (LA), left ventricular mass (LVM). 
age event free survival in patients with severe AS with CAD is $24.7 \pm 2.9$ months, in comparison with $27.5 \pm 1.9$ months in patients with severe AS without CAD. In point of fact, applying the log rank test on Kaplan-Meier's survival curves, showed insignificant average event free survival $(\mathrm{p}=0.35)$ between patients with severe AS with and without CAD $(n=142)$ (Figure 2.A).

Concerning the event occurrence, there was no significant risk of event occurrence $(p=0.36)$, between both groups of patients with severe AS (with and without CAD), $(\mathrm{n}=142)$ (Figure 2.B).

If we take a look at the two groups of patients with severe AS (142 patients) who have undergone coronary angiography (with and without CAD), in terms of the distribution of asymptomatic and symptomatic patients, we can see that: of all patients with CAD, $87.8 \%$ have symptoms, compared to $74.3 \%$ who do not have CAD and have symptoms. (Table 9). Frequency distribution analysis of asymptomatic and symptomatic AS patient's vs. coronary angiography findings (AS patients with/without CAD), show
NP negatively correlates with AVA and LVEF, whether positive correlation was expressed for: LVEDd, LVEDs, IVSd, AV_Vmax, AV_MaxGrad, LVM and LA ( $\mathrm{n}=187)$.

In order to check the probability of event occurrence, multivariate logistic regression analysis was implemented including: clinical findings: aging, systolic blood pressure, obesity, laboratory parameters: hematocrit (Hct), Nt-proBNP and echocardiographic parameters: AV Vmax, AVA, LVEDs and LVEF. As predictors for event occurrence were only: Nt-proBNP with an odds ratio (OR) of $1.0(95 \%$ CI 1.001 to $1.003, \mathrm{p}<0.001)$ and $A V_{-}$Vmax with an OR $3.4(95 \%$ CI 1.34 to $8.70, p<0.01)$. Furthermore, including only Nt-proBNP and AV_Vmax in the same analytical model, resulted with a significant prediction of event occurrence determined only by Nt-proBNP with an OR 1.36 (95\% CI 1.11 to $1.65, \mathrm{p}<0.002)(\mathrm{n}=187)$.

Association of Nt-proBNP with Event Occurrence and Survival

Analysis of the frequency of events in the
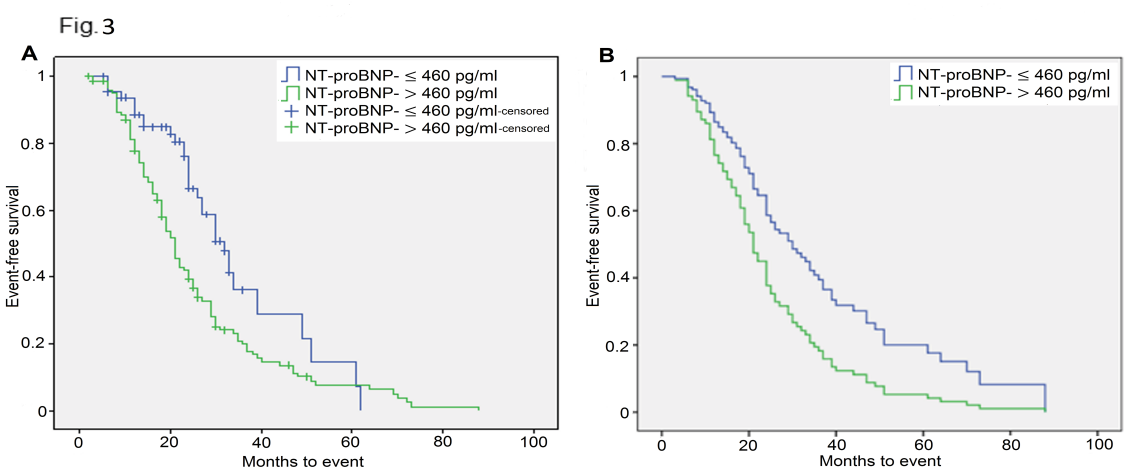

Figure 3. A: Kaplan-Meier event free survival curves in all 187 patients divided according to Nt - proBNP above and below the cut-off of $460 \mathrm{pg} / \mathrm{ml}$.

B: Kaplan-Meier event-free survival curves in AS patients without CAD $(n=101)$ divided according to obtained NtproBNP cut-off value.

insignificant differences $(\mathrm{p}=0.077)$.

\section{Association between Nt-proBNP and Echocardiography}

All examined echocardiographic parameters are presented in Table 10.a. Our analysis indicates significant differences between asymptomatic and symptomatic patients for: LVEF, AV_Vmax, AV_MaxGrad, AVA $(\mathrm{n}=187)$ $(\mathrm{p}<0.0001$, for all respectively).

Correlation between Nt-proBNP and echocardiographic parameters is shown in Table 10.b. From presented results it is evident that Nt-proB- whole group of patients $(n=187)$, showed that $77.1 \%$ who got(reach) event were patients with a Nt-proBNP value above cut-off, compared to $34 \%$ patients with Nt-proBNP above the cut off without events. The difference is statistically significant $(\mathrm{p}<0.0001)$ (Table 11).

Kaplan-Meier event free survival (analyzed in all 187 patients) outlined that the average event free survival in patients with Nt-proBNP above the cut-off is $25.6 \pm 1.7$ months $(95 \% \mathrm{CI}$ 22.3 to 29 ), in comparison with $33.9 \pm 2.7$ months in patients with Nt-proBNP below the cut-off (95\% CI 28.5 to 39.4). Applying the log rank test on the Kaplan-Meier curves, showed that the 
Table 11. Frequency of events in the whole group of patients $(n=187)$ according to Nt-proBNP cut-off

\begin{tabular}{|c|c|c|c|}
\hline & \multicolumn{2}{|c|}{ Event status } & \multirow[b]{4}{*}{ Total } \\
\hline & Censored & Reached event & \\
\hline & (lost or death & (symptom & \\
\hline & from other cause) & and/or death) & \\
\hline Nt-proBNP $(\leq 460$ pg/ml; n. \%) & $31(66.0)$ & $32(22.9)$ & $63(33.7)$ \\
\hline Nt-proBNP (> 460 pg/ml; n. \%) & $16(34.0)$ & $108(77.1)$ & $124(66.3)$ \\
\hline Total (n. \%) & $47(100)$ & $140(100)$ & $187(100)$ \\
\hline
\end{tabular}

Abbreviation for Nt-proBNP is the same as in Table 3.

group with Nt-proBNP above the cut-off has significantly lower event free survival $(\mathrm{p}<0.004)$, in comparison with counterparts with Nt-proBNP below the cut-off (Figure 3.A).

We obtained the same results when we analyzed event free survival for 101 AS patients without CAD. The Kaplan-Meier's event free survival curves comparisons with the log rank test among the AS patients without CAD $(n=101)$ divided according the Nt-proBNP cut-off, resulted with significantly lower event free survival $(p<0.025)$, for the patients with Nt-proBNP above the cut-off value. Average event free survival in the group with Nt-proBNP above the cut-off is $24.7 \pm 2.1$ months (95\% CI 20.4 to 29$)$, in comparison with $33.4 \pm 3.2$ in the patients with Nt-proBNP below the cut off (95\% CI 27.1 to 39.7), (Figure 3.B).

Sensitivity and Specificity of Nt-proBNP, $A V A$ and $A V \_V \max$

Sensitivity and specificity of the Nt-proBNP, AVA and AV_Vmax as predictors for symptom detection, were determined by ROC curve analysis (Figure 4). The optimal cut-off value of Nt-proBNP for symptom detection was $460 \mathrm{pg} / \mathrm{ml}$ with $85 \%$ sensitivity, $72 \%$ specificity, $86 \%$ positive predictive value and $70 \%$ negative predictive value. Nt-proB$\mathrm{NP}$ having the highest predictive value for symptom occurrence with an area under the curve (AUC) 0.8 $(p<0.0001)$. AVA was the weak predictive value for symptom occurrence with AUC $0.33(\mathrm{p}<0.0001)$. $\mathrm{AV}$ _Vmax had predictive values between AVA and Nt-proBNP, with AUC $0.69(\mathrm{p}<0.0001)$.

\section{The Role of Nt-proBNP in AVR Prediction}

By applying the Cox regression analysis, Nt-proBNP significantly predicted the risk for AVR reference with HR 1.45 (95\% CI 1.02 to 2.06$)$, in the patients with Nt-proBNP values above the limit of $460 \mathrm{pg} / \mathrm{ml}$, compared with the group with Nt-proB$\mathrm{NP}$ below the limit value $(\mathrm{n}=187)$ (Figure 5).

\section{DISCUSSION}

The natriuretic peptides, atrial natriuretic peptide (ANP), predominantly produced in the atrium and brain natriuretic peptide (BNP), predominantly produced in ventricles, represent cardiac neurohormones. They are secreted by myocardial cells in response to increased wall stress - stretching of the myocardium due to pressure/ volume overload. Their effects are: natriuresis, peripheral vasodilatation, decreased sympathetic and RAAS system activity, and inhibition of endothelin release. [8] With increased diuresis, reducing the pressure of ventricle loading and blood pressure decreasing, this endogenous heart hormone system is a natural antagonist of the renin-angiotensin-aldosterone system.

Figure 4. ROC curve of the sensitivity and specificity of NT-proBNP, AVA and AV_Vmax as predictors in symptom occurrence. The blue line represents the non-discrimination curve; $(p<0.0001$; $A U C$ is $0.8 ; 0.33$; and



0.69; for NT-proBNP, AVA and AV_Vmax, respectively). 
BNP represents 108 (1-108) amino acid peptide that breaks down on the biologically active Pro-BNP (77-108) and the biologically inactive N-terminal fragment - Nt-proBNP (1-76).

The biologically active form of BNP is rapidly metabolized and inactivated in the circulation by specific enzymes - neutral endopeptidases and by specific cell surface receptor clearance. Biologically inactive Nt-proBNP has a longer half-life, lower degradation, circulates longer in plasma and in larger concentrations than the active form [9]. The half-life of Nt-proBNP is $120 \mathrm{~min}$, and it may reflect haemodynamic changes at approximately 12 hours. [10] The half-life of the biologically active BNP is 22 minutes, but it may reflect a change in capillary vein pressure in the lungs for two hours. [11] It has been shown in vitro that these peptides lead to the inhibition of collagen synthesis from cardiac fibroblasts which has protective role in reducing diastolic compliance during left ventricular hypertrophy. [12]

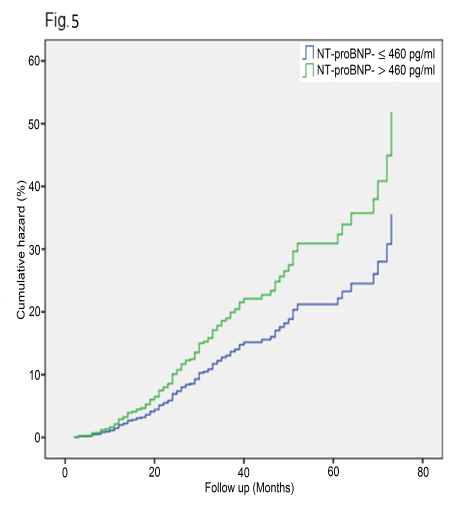

Figure 5. Cumulative hazard for AVR reference in all 187 aortic stenosis patients divided according $N t$ - proB$\mathrm{NP}$ above and below the cut-off of $460 \mathrm{pg} / \mathrm{ml}$.

In pathological conditions affecting ventricles (hypertrophy of the left ventricle or heart failure), the BNP level increases several times as a consequence of increased wall stress. Increased BNP values help in the diagnostic dissection between cardiac and non-cardiac dyspnea, indicating early stage of heart disease, before some clinical symptoms to be manifested. Its levels are increased in various heart diseases such as: acute heart attack, chronic heart failure and primary pulmonary hypertension. But also, in recent years, BNP has been shown to be extremely important in valvular aortic stenosis, as this disease initially leads to diastolic and later to systolic left ventricular dysfunction. In aortic stenosis, BNP has been shown to be a strong independent predictor of the clinical outcome, the severity of the disease, and the symptomatic status. It appears as a marker that predicts new symptoms in patients with asymptomatic severe AS. It appears as a strong independent predictor of mortality. Hence, its significance in the prediction of the period for aortic valvular replacement, especially in asymptomatic patients with severe AS. $[13,14]$

In our examined patient series, we received a significant positive correlation between the age of patients and the value of Nt-proBNP $(r=0.21$, $\mathrm{p}<0.003$ ). Asymptomatic patients with severe AS, also had markedly elevated Nt-proBNP values.

Symptomatic patients have significantly higher values of Nt-proBNP compared to asymptomatic patients $(p<0.0001)$, which means that the increased degree of disease is also accompanied by higher values of this parameter. In the natural history of aortic valvular stenosis, there is gradual deterioration, with the replacement of diastolic dysfunction with systolic dysfunction of the left ventricle. It is manifested through a transition to a more pronounced degree of NYHA functional class. This deterioration was manifested by a significant difference between the mean values of Nt-proBNP in all three NYHA functional classes (ANOVA, $\mathrm{p}<$ 0.0001), which means that Nt-proBNP is a significant predictor of future clinical deterioration.

Gerber et al. (2003), [15] found that the Nt-proBNP values were significantly higher in symptomatic compared to asymptomatic patients and were also significantly higher with the rise of NYHA class, which corresponds to our results.

In our study, Nt-proBNP was confirmed as a statistically significant predictor of the risk of occurrence (symptom and/or death), i.e. it increased the risk by 1.4 times.

In the Cox multivariate regression analysis, NT-proBNP was the only determinant of event occurrence when prediction was related to NYHA III and AV Vmax. In relation to the NYHA II, the event occurrence was determined by: Nt-proBNP and the functional class NYHA II as well. In addition, a multivariate logistic regression model based on: clinical: (aging, systolic blood pressure, obesity), laboratory: (Hct, Nt-proBNP) and echocardiographic parameters: (AV Vmax, AVA, LVEDs and EF), outlined two predictors of event occurrence: NT-proBNP and AV_Vmax. The same analytical subset based on NT-proBNP and AV_Vmax only, predicts events only by NT-proBNP. We can conclude that 
NT-proBNP can be used as a significant predictor of risk for future adverse events. In the penultimate (2012) and last (2017) European Guidelines for management of valvular heart disease, this is exactly what was proposed. $[1,2]$

In the analysis of our examined series of patients with severe AS we paid special attention to the group (101 patients), where coronary angiography did not confirm the existence of significant coronary vessel stenosis. In this way, the influence of CAD on the development and progression of AS, the influence on the values of Nt-proBNP, as well as the influence on all other studied parameters was excluded.

In the group of AS patients without CAD $(n=101)$, we analyzed patients with and without chest pain, with and without fatigue, with and without syncope, respectively, in relation to Nt-proBNP cut-off value. Thereby statistically significant differences were obtained in favor of patients with chest pain, fatigue and syncope, with Nt-proBNP above the cut-off value. This shows that Nt-proBNP is a significant parameter indicating the typical symptoms of aortic valvular stenosis, especially since this analysis excludes the impact of CAD in the manifestation of eventual symptomatology.

Figure 1 shows the frequency distribution from the obtained Nt-proBNP values in all 187 patients. It is more than evident that the majority of patients with severe AS without CAD have very high values for $\mathrm{Nt}$-proBNP.

Also, in the group with regular coronary angiography $(n=101), 69.3 \%$ of patients had Nt-proBNP above the cut-off value of $460 \mathrm{pg} /$ $\mathrm{ml}$, and $30.7 \%$ had values below the cut-off value $(p<0,05)$, which indicates that in our examined series of patients with severe valvular AS, we have a higher percentage of patients with high values of this parameter (above the cut-off value).

From 101 patients without CAD, of all the symptomatic patients, a higher percentage were patients with NT-proBNP values above the cutoff, compared to asymptomatic patients with Nt-proBNP values above the cut-off $(p<0.0001)$. From this statistic we can conclude that faster disease progression is typical for symptomatic patients with higher Nt-proBNP values.

In this analysis we found something very important. Within the asymptomatic patients with normal coronary angiography findings, $23.1 \%$ were found with Nt-proBNP values above the cut-off of $460 \mathrm{pg} / \mathrm{ml}$. These patients deserve special attention because they do not manifest any symptom, although severe AS was present. Such high Nt-proBNP value represents the unique biochemical parameter that needs greater attention due to the expectation of future events, complications, or sudden cardiac death. In fact, this is the group where the impact of CAD is excluded and all events are only the results of severity of AS. Therefore, Nt-proBNP does not have a meaning only in the assessment of the severity of the disease, but also it is especially important in predicting future events or even sudden cardiac death in asymptomatic patients with severe AS (Table 7).

Lim and co. (2004) [16], evaluated the prognostic value of BNP in symptomatic and asymptomatic patients with severe AS and preserved LV function. BNP values have been increased in the presence of symptoms, and with the increase in NYHA functional class. BNP serum $>66 \mathrm{pg} / \mathrm{ml}$ was evaluated as a cut-off value, which revealed symptomatic patients with sensitivity, specificity and accuracy of $84 \%, 82 \%$ and $84 \%$ respectively. BNP levels were a strong independent predictor of cardiovascular death regardless of whether the patients were symptomatic or asymptomatic. The results of this study regarding the symptomatic status and NYHA functional class correspond to the results of our study. We can conclude that serum BNP and Nt-proBNP values allow a distinction between symptomatic and asymptomatic patients with severe AS, which can be an independent predictor of outcome in these patients and may be useful at risk stratification when referring to AVR.

The occurrence of symptoms in patients with AS plays a key role in making decisions for optimal time for the AVR. On the other hand, the assessment of clinical symptoms in clinical routine remains a major challenge. Therefore, BNP and Nt-proBNP seem to be suitable objective parameters for evaluating patients with $\mathrm{AS}$, in addition to clinical assessment and echocardiography, especially if there is uncertainty whether the patient is symptomatic or not. [1,2]

In our examined series, in the Nt-proBNP group above the cut-off value of $460 \mathrm{pg} / \mathrm{ml}$, in groups with severe AS with and without $C A D$, we received significant difference $(p<0.05)$ in favor of greater prevalence of patients with severe AS who do not have a CAD. This means that the occurrence of high values of Nt-proBNP (above the 
cut-off value) does not depend on the presence of CAD, but only on the severity of AS ( $n=142)$.

We found that there was no statistically significant difference $(p=0.35)$ in the average event free survival between patients with severe AS with CAD compared to patients without CAD. We did not receive significant difference between the mean values of Nt-proBNP in the same groups: patients with severe AS with CAD compared to patients without CAD ( $p$ $=0.25)$ in our examined series $(n=142)$.

The analysis of the frequency distribution of Nt-proBNP groups above and below the cutoff value among the groups with/without CAD in patients with severe AS, showed that there was no significant difference $(p=0.09)$. This once again showed that high values of Nt-proBNP are not closely related to CAD.

Although we thought that patients with severe AS with CAD had a higher risk of event occurrence compared to patients with severe AS without CAD, employed statistical analysis showed that in our series of 142 patients (101 ptc. with regular findings and 41 with CAD), there is no significant bigger risk for patients with severe AS with $\mathrm{CAD}$, to receive an event occurrence rapidly $(\mathrm{p}=0.36)$.

Analysis of the frequency distribution of asymptomatic and symptomatic patients in relation to the presence or absence of CAD showed that there was no significant difference between them $(p=0.077)$. This confirms that the existence of symptoms in patients with severe AS does not depend on present CAD.

In order to determine the cut-off value of Nt-proBNP in the monitoring of patients with AS, we compared the echocardiographic parameters with the cut-off value of Nt-proBNP and we got the following: symptomatic patients had higher mean values of: transvalvular flow velocity, transvalvular gradient and Nt-proBNP, while lower mean values of: AVA and EF, compared to asymptomatic patients.

In our study, we found that the levels of Nt-proBNP were positively correlated with AS severity, as indicated by NYHA, LVEDd, LVEDs, IVSd, AV_Vmax, AV_MaxGrad, LVM and LA, and had a negative correlation with AVA and LVEF. Many studies demonstrate an inverse correlation between higher levels of natriuretic peptides and ejection fraction in patients with AS, suggesting that adaptive process becomes maladaptive when exceeding physiological limits. This parameter may be useful to detect this maladaptive transition to increased LV dimensions and reduced LV function.

We have analyzed the occurrence of events in relation to the cut-off value of Nt-proBNP of $460 \mathrm{pg} / \mathrm{ml}(\mathrm{n}=187)$, and we obtained statistical significance $(p<0.0001)$, which means that there were higher percentage distribution of patients having an event occurrence and Nt-proBNP above the cut-off value at the same time.

The average event free survival in patients with Nt-proBNP above and below the cut-off value of $460 \mathrm{pg} / \mathrm{ml}$ analyzed between all $187 \mathrm{pa}-$ tients and 101 patients without $\mathrm{CAD}$, showed a significant difference $(p<0.004 ; p<0.025$ respectively), obtained by comparing the Kaplan-Meier curves with the log rank test. Patients with a Nt-proBNP value above the cut-off of $460 \mathrm{pg} /$ $\mathrm{ml}$ had a statistically significant shorter time of event free survival.

Our study showed that from all three tested symptom predictors (Nt-proBNP, AVA and AV Vmax), Nt-proBNP have the highest predictive values for symptom occurrence, with the highest area under the ROC curves (Fig. 4). Nt-proBNP of $>460 \mathrm{pg} / \mathrm{ml}$ was our cut off value, with a sensitivity of $85 \%$ and a specificity of $72 \%$ to predict symptom occurrence in severe AS.

In addition, by applying the Cox regression analysis, Nt-proBNP was classified as a significant predictor of the risk for AVR reference in patients with Nt-proBNP above the cut off $(n=187)$. Thus, the Nt-proBNP threshold is critical to this study.

Bergler-Klein and cow. (2004), [17] confirmed the close correlation of BNP with symptom status in severe AS. Between asymptomatic patients with AS, higher BNP and Nt-proBNP levels had those patients who developed symptoms. They found that the presence of CAD did not affect neurohormonal levels, which is the same as in our study. Nt-proBNP at baseline was the only independent predictor for postoperative survival, while BNP, AVA, EF, NYHA and age did not appear as predictors. Only Nt-proBNP and $\mathrm{EF}$ were independent predictors of event free survival in patients treated conservatively. $\mathrm{BNP}<130 \mathrm{pg} / \mathrm{mL}$ and plasma Nt-proBNP levels $<592 \mathrm{pg} / \mathrm{mL}$ were less likely to progress to the symptoms and required surgical treatment for the next 6 to 9 months ( $90 \%$ and $88 \%$ symptom free survival, respectively). This important study 
supports a possible strategy of watchful waiting with assessment of BNP as an integral part of managing asymptomatic patients.

Weber and co. (2005), in a study that included patients with aortic valve stenosis and aortic valve failure, established a significant decline in Nt-proBNP levels after AVR surgery, while in conservatively treated patients, Nt-proBNP levels have increased in favor of worsening of their clinical condition. [18] In the next study Weber et al. (2006) in patients with AS showed an independent predictive value of Nt-proBNP for mortality and decompensated cardiac failure with a cut-off value of $640 \mathrm{pg} / \mathrm{ml}$, comparable to the cut-off value given in the study of Bergler-Klein et al. [17] In patients treated conservatively, the increased value of Nt-proBNP was associated with a significantly increased risk of death and heart failure. [19] The cut-off value of $460 \mathrm{pg} / \mathrm{ml}$ in our study is considered to be very similar to the results of these authors.

Recently published reports suggest that BNP and Nt-proBNP can be applied for risk stratification of patients with AS, especially in patients who are not considered for valvular surgery and therefore treated conservatively. Therefore, BNP and Nt-prBBNP values can be useful diagnostic parameters in order to decide about the optimal time for valvular surgery. There is evidence that BNP and Nt-proBNP are useful for evaluating patients with AS, especially if there are unreliable data for a positive symptomatic status in a patient. Because of this, BNP and Nt-proBNP serum levels were suggested, in addition to clinical and echocardiographic assessment. [1, 2, 20, 21] It is not specified which BNP and Nt-proBNP level will be considered increased. According to existing data, a practically decisive level for BNP from a mean of 100-150 $\mathrm{pg} / \mathrm{ml}$ and a mean $600 \mathrm{pg} / \mathrm{ml}$ of Nt-proBNP were taken as susceptible. However, additional data from prospective studies is required. In this direction, we consider that our specific cut-off value of $460 \mathrm{pg} / \mathrm{ml}$ of Nt-proBNP is very similar to the value given by these authors.

In the recommendations for monitoring and treatment of patients with valvular heart disease in 2012, [1] published by ESC, for the first time a serial determination of Nt-proBNP was recommended and was officially incorporated in the indications for referral to the AVR for asymptomatic patients with AS, which is also included in the recent Recommendations of 2017. [2] Thus in class
IIaC is given: the AVR may need to be considered if there is a normal LV, EF, none of the exercise test abnormalities, if the surgical risk is low and one or more of the following findings are present: a) significant increase in the values of $\mathrm{BNP} /$ Nt-proBNP ( $>3$ times, for age and sex corrected normal values), confirmed by repeated measurements, with no other explanations; b) very severe aortic stenosis defined by maximal transvalvular velocity above $5.5 \mathrm{~m} / \mathrm{s}$; c) heavy valve calcification and annual progression of transvalvular velocity $>0.3 \mathrm{~m} / \mathrm{s} /$ year; e) severe pulmonary hypertension (systolic pulmonary arterial pressure in peace $>60 \mathrm{~mm} \mathrm{Hg}$ confirmed by invasive measurements), without other explanations. In addition, non-cardiac causes of increased (i.e., chronic renal disease) or decreased (i.e., obesity) levels of natriuretic peptides should be considered. Examining natriuretic peptide trends have been useful in our experience because relative changes may be more meaningful than absolute values in the assessment of patients with asymptomatic severe AS. [22]

\section{CONCLUSION}

In conclusion, our study gives some new insight into the Nt-proBNP predictive meanings concerning severe AS. In our study group, the Nt-proBNP cut off $>460 \mathrm{pg} / \mathrm{ml}$ has been confirmed as a useful tool in the determination of event free survival in patients with severe AS, in all pts. and in the group without CAD. Nt-proBNP doesn't have meaning only in the assessment of the severity of disease, but is also especially important as a predictor with significant influence on the risk of event occurrence. Faster disease progression, is typical for patients with higher Nt-proBNP values. From all tested symptom predictors (Nt-proBNP, AVA and AV Vmax), Nt-proBNP have the highest predictive value for symptom occurrence in patients with severe AS. In addition, this study found that regular measurement of Nt-proBNP can provide important information about the risk for AVR reference in patients with severe AS.

\section{Financial disclosure}

There is no financial disclosure. 
Abbreviations: aortic stenosis (AS), aortic valve area (AVA), aortic valve replacement (AVR), coronary artery disease (CAD), left ventricular ejection fraction (LVEF), LV mass (LVM), maximal aortic transvalvular velocity (AV_Vmax), maximal transvalvular gradient (AV_Max.Grad), N-terminal pro-brain natriuretic peptide (Nt-proBNP), New York Heart Association (NYHA), receiver operating characteristics (ROC).

\section{REFERENCES}

1. Vahanian A, Alfieri $\mathrm{O}$, Andreotti $\mathrm{F}$ et al. The Joint Task Force on the Management of Valvular Heart Disease of the European Society of Cardiology (ESC) and the European Association for Cardio-Thoracic Surgery (EACTS). Guidelines for the management of valvular heart disease (version 2012). European Heart Journal 2012; 33: 2451-2496.

2. Baumgartner H, Falk V, Bax JJ, et al. ESC/ EACTS Guidelines for the management of valvular heart disease, European Heart Journal 2017; 38: 2739-2791

3. Bonow RO, Carabello BA, Chatterjee $\mathrm{K}$, et al. American College of Cardiology/American Heart Association Task Force on Practice Guidelines. 2008 focused update incorporated into the ACC/AHA 2006 guidelines for the management of patients with valvular heart disease, J Am Coll Cardiol 2008; 52: 1-142.

4. Schiller NB, Shah PM, Crawford M et al. Recommendations for quantitation of the left ventricle by two-dimensional echocardiography: American Society of Echocardiography Committee on Standards, Subcommittee on Quantitation of Two-Dimensional Echocardiograms. J Am Soc Echocardiogr 1989; 2: 358-367.

5. Popescu BA, Andrade MJ, Badano LP, et al. European Association of Echocardiography recommendations for training, competence, and quality improvement in echocardiography. Eur J Echocardiogr 2009; 10: 893-905.

6. Baumgartner H, Hung J, Bermejo J, et al. Echocardiographic assessment of valve stenosis: EAE/ ASE recommendations for clinical practice. Eur $\mathrm{J}$ Echocardiogr 2009; 10: 1-25.

7. Rosenhek R, Maurer G, Baumgartner H. Should early elective surgery be performed in patients with severe but asymptomatic aortic stenosis. EHJ 2002; 23: 1417-1421.
8. Struthers AD. Ten years of natriuretic peptide research: a new dawn for their diagnostic and therapeutic use. BMJ 1994; 308: 1615-9.

9. Buckley MG, Marcus NJ, Yacoub MH et al. Prolonged stability of BNP: importance for non-invasive assessment of cardiac function in clinical practice. Clin Sci 1998;95:235-9.

10. Roche Diagnostics. Pro-Brain natriuretic peptide package insert. Indianapolis 2002; Roche Diagnostics.

11. Kazanegra R, Cheng V, Garcia A, et al. A rapid test for B-type natriuretic peptide correlates with falling wedge pressures in patients treated for decompensated heart failure: a pilot study. J Card Fail 2001; 7: 21-9.

12. Qi W, Mathisen P, Kjekshus J, et al. Natriuretic peptides in patients with aortic stenosis. Am Heart J 2001; 142: 725-32.

13. Salehian O, Chan LK. Should brain natriuretic peptides be measured in patients with aortic valve disease. Eur H J 2005; 26: 951-952.

14. Baumgartner H. Aortic stenosis: medical and surgical management, Heart 2005; 91: 1483-1488.

15. Gerber IL, Stewart RA, Legget ME, et al. Increased plasma natriuretic peptide levels reflect symptom onset in aortic stenosis. Circulation. 2003; 107: 1884-1890.

16. Lim P, Monin LJ, Monchi M, et al. Predictors of outcome in patients with severe aortic stenosis and normal left ventricular function: role of B- type natriuretic peptide. Eur H J. 2004; 25: 2048-2053.

17. Bergler-Klein J, Klaar U, Heger M, et al. Natriuretic peptides predict symptom-free survival and postoperative outcome in severe aortic stenosis. Circulation. 2004; 109: 2302-2308.

18. Weber M, Arnold R, Rau M, et al. Relation of $\mathrm{N}$-terminal pro B-type natriuretic peptide to progression of aortic valve disease. Eur H J 2005; 26: 1023-1030.

19. Weber M, Hausen M, Arnold R, et al. Prognostic value of $\mathrm{N}$-terminal pro-B-type natriuretic peptide for conservatively and surgically treated patients with aortic valve stenosis. Heart 2006; 92: 1639-1644.

20. Otto Catherine M, FACC. Valvular aortic stenosis: disease severity and timing of intervention. J Am Coll Cardiol 2006; 47: 2141-51.

21. Vahanian A, Otto CM. Risk stratification of patients with aortic stenosis. European Heart Journal (2010)31, 416-423

22. Parikh V, Kim C, Robert J. et al. Natriuretic peptides for risk stratification of patients with valvular Aortic Stenosis, Circ Heart Fail. 2015; 8: 373-380. 


\title{
Резиме
}

\section{Nt-proВNP ДИСКРИМИНАТОРНА УЛОГА МЕЃУ СИМПТОМАТСКИТЕ И АСИМПТОМАТСКИТЕ ПАЦИЕНТИ СО ТЕШКА ВАЛВУЛАРНА АОРТНА СТЕНОЗА}

\author{
Емилија Антова ${ }^{1}$, Лидија Петковска ${ }^{2}$, Маријан Бошевски ${ }^{1}$, Јагода Стојковиќ ${ }^{3}$, \\ Никола Хаџи-Петрушев ${ }^{4}$, Андре Камкин ${ }^{5}$, Митко Младенов ${ }^{4,5}$
}

\footnotetext{
${ }^{1}$ Медицински факултет, Универзитетска клиника за кардиологија, Универзитет „Св. Кирил и Методиј“, Скопје, Република Македонија

${ }^{2}$ Медицински факултет, Универзитетска клиника за токсикологија, Универзитет „Св. Кирил и Методиј“, Скопје, Република Македонија

${ }^{3}$ Медицински факултет, Универзитетска клиника за пулмологија, Универзитет „Св. Кирил и Методиј“, Скопје, Република Македонија

${ }^{4}$ Природно-математички факултет, Институт за биологија, Универзитет „Св. Кирил и Методиј“, Скопје, Република Македонија

${ }^{5}$ Оддел за фундаментална и применета физиологија, Руски национален истражувачки медицински универзитет, Русија
}

Вовед: Целта на истражувањето беше да се процени дискриминаторската улога на Nt-proBNP меѓу симптоматските и асимптоматските пациенти со тешка валвуларна аортна стеноза (AS)

Методи: Анализирани беа 187 пациенти (птц.) со тешка валвуларна аортна стеноза, со нормална EF $>50 \%$, од кои 61 беа асимптоматски и 126 симптоматски. Беа следени клиничките, лабораториските (Nt-proBNP) и ехокардиографските параметри. Крајни точки на следење (појава на збиднување) беа: појавата на симптоми кај асимптоматските птц. и појавата на смрт кај обете групи.

Резултати: Симптоматските птц. со тешка AS се карактеризираа со значајно повисоко просечно ниво на Nt-proBNP во споредба со асимптоматските. Nt-proBNP претставуваше моќен предвидувачки фактор на ризик од појава на збиднување (HR 1,4). Во рамките на групата на птц. со тешка AS без коронарна артериска болест (CAD) (n=101), подгрупата со ниво на Nt-proBNP повисоко од граничната вредност опфаќаше значајно повисок процент на птц. со болки во градите, замор и синкопа. Групата co Nt-proBNP над граничната вредност содржеше значајно повисок процент на птц. со тешка AS без CAD, во споредба со помалиот процент на застапеност на тие што имаа CAD. Постоеше негативна корелација меѓу нивото на Nt-proBNPи AVA и LVEF, додека позитивна корелација беше констатирана во однос на: LVEDd, LVEDs, IVSd, AV_Vmax, AV_MaxGrad, LVM и LA. Пациентите co ниво на Nt-proBNP над граничната вредност имаа значително пократко преживување без збиднување, во споредба со птц. чие ниво на Nt-proBNP беше под граничната вредност (n=187; n=101).

Заклучок: Беше потврдено дека граничната вредност на Nt-proBNP од $>460 \mathrm{pg} / \mathrm{ml}$ претставува корисна алатка во одредувањето на преживување без збиднување кај птц. со тешка AS. Овој параметар не само што беше значаен при проценката на тежината на заболувањето туку се покажа и како значаен предиктор на ризикот од појава на збиднување.

Клучни зборови: аортна стеноза; $\mathrm{N}$-терминален про-Б-тип натриуретичен пептид; ехокардиографија; аортен валвуларен репласман 